Sains Peternakan Vol. 13 (1), Maret 2015: 57-65

ISSN 1693-8828

\title{
Pengaruh Proteksi Aldehid Untuk Meloloskan Poly Unsaturated Fatty Acid Pada Menir Kedelai dan Minyak Ikan Lemuru Secara In Vitro
}

\author{
Riyanto, $\mathbf{J}^{1,2}$., E. Baliarti ${ }^{3}$ L. M. Yusiati ${ }^{3}$., T. Hartati ${ }^{3}$ dan D.T. Widayati ${ }^{3}$ \\ ${ }^{1}$ Program Doktor Pascasarjana Fakultas Peternakan, Universitas Gadjah Mada \\ ${ }^{2}$ Jurusan Peternakan, Fakultas Pertanian, Universitas Sebelas Maret \\ ${ }^{3}$ Fakultas Peternakan, Universitas Gadjah Mada \\ Email: jokoriyanto19@yahoo.com
}

\begin{abstract}
ABSTRAK
Penelitian ini bertujuan mengetahui pengaruh penggunaan formaldehid sebagai materi proteksi campuran menir kedelai dan minyak ikan lemuru untuk meloloskan protein dan poly unsaturated fatty acid (PUFA) secara in vitro. Cairan rumen diperoleh dari donor sapi PO betina berfistula sebanyak 3 ekor. Rancangan percobaan menggunakan Rancangan Acak Lengkap pola Faktorial 2x3 terdiri dari 2 faktor yaitu faktor pertama (menir kedelai:minyak ikan lemuru dengan rasio 2:1 dan 4:1) dan faktor kedua (penggunaan formaldehid dengan level $0 \%, 2 \%$ dan $4 \%$ dari bahan kering) dan diulang 5 kali. Parameter terdiri dari kandungan nutrien, kadar PUFA substrat campuran menir kedelai dan minyak ikan lemuru dan hasil fermentasi cairan rumen secara in vitro. Hasil penelitian adalah kadar protein, asam lemak oleat, linoleat dan arachidonat banyak tersedia pada menir kedelai:minyak ikan lemuru terproteksi formaldehid pada level $2 \%$ dan 4\%. Perbedaan rasio antara menir kedelai dengan minyak ikan lemuru berbeda tidak nyata $(\mathrm{P} \geq 0,05)$ namun berbeda nyata pada perbedaan level formaldehid $(\mathrm{P} \leq 0,05)$. Kesimpulan formaldehid kadar $37 \%$ dengan level $2 \%$ dapat digunakan untuk proteksi campuran menir kedelai dan minyak ikan lemuru dengan rasio 4:1 dan mampu menyediakan protein sekaligus PUFA.
\end{abstract}

Kata Kunci: menir kedelai, minyak ikan lemuru, in vitro, PUFA, proteksi formaldehid.

\section{Effect Of The Aldehydes Protection to Escape Of Poly Unsaturated Fatty Acid In The Soybean Groat and Lemuru Fish Oil By In Vitro}

\begin{abstract}
This research was aims to determine the effect of formaldehyde using as a protective material in the soy groats and lemuru fish oil mixtured to escape of the protein and poly unsaturated fatty acid (PUFA) by in vitro. The rumen fluid was derived from donor of the Ongole crosbred fistulated as much as 3 heads. The experimental design used completely randomized design factorial $2 \times 3$ pattern consists of two factors:the first factor (soybean groats:lemuru fish oil in the ratio 2:1 and 4:1) and the second factor (the use of formaldehyde at levels of 0\%, 2\% and 4\% base on the dry matter) and was repeated 5 times. The parameters are consist of the nutrient content, the substrates soybean groats and lemuru fish oil the rumen fluid fermented PUFA content by in vitro. Results of the study are levels of protein, fatty acids oleic, linoleic and arachidonic much available on soybean groats:lemuru fish oil protected formaldehyde at levels of $2 \%$ and $4 \%$. The difference between the ratio of soybean groats with lemuru fish oil had no significant $(P \geq 0,05)$ but significantly different at different levels of formaldehyde $(P \leq 0,05)$. The conclusion are formaldehyde content of $37 \%$ with a level of $2 \%$ can be used for protection the soybean groats and lemuru fish oil with a ratio of 4:1 and is able to provide protein as well PUFA.
\end{abstract}

Keywords: soy groats, lemuru fish oil, in vitro, PUFA, formaldehyde protection 


\section{PENDAHULUAN}

Menir kedelai selain sebagai sumber asam linoleat (C18:2 n-6) atau asam lemak omega-6 dan asam arakidonat (C20:4 n-6) juga sumber protein sedangkan minyak ikan lemuru sumber asam linolenat (C18:3 n-3) atau asam lemak omega-3. Kedua asam lemak tersebut mampu memperbaiki kinerja reproduksi dan produktivitas induk sapi. Asam lemak tak jenuh ganda selama proses pencernaan di rumen mengalami proses hedrogenasi oleh mikrobia rumen menjadi asam lemak jenuh (Lourenc et al., 2010). Untuk itu diperlukan perlakuan proteksi bahan pakan agar supaya PUFA sekaligus protein dapat lolos dari hidrogenasi atau rumen bypass fat-protein hingga diserap di usus halus. Proteksi PUFA pada bahan pakan dapat menggunakan aldehid dari formaldehid untuk proteksi tepung serealia (MohammadianTabrizi et al., 2011), menir kedelai (Riyanto et al., 2011), tepung kedelai dan linseed (Dirandeh et al., 2013).

Metode proteksi protein-lemak ini dilakukan melalui pemanfaatan matrik protein bahan pakan untuk berikatan dengan aldehid dari formaldehid didasarkan atas penurunan kecernaan protein akibat dari perubahan struktur tiga dimensi oleh aldehid. Struktur denaturasi protein tersebut dapat dipecah oleh enzim protease, pankreas dan intestinum (Wallace dan Cotta, 1988). Kajian terkait dengan hasil proteksi berbagai bahan pakan menggunakan formaldehid belum banyak diketahui. Proteksi dalam penelitian ini menggunakan aldehid dari formaldehid kadar $37 \%$ bertujuan selain meloloskan PUFA dari hedrogenasi juga protein pakan.

\section{METODE PENELITIAN}

\section{Waktu dan Tempat}

Penelitian telah dilaksanakan mulai bulan November 2012 sampai dengan April 2013. Penelitian dilaksanakan di Laboratorium Biokimia Nutrisi Fakultas Peternakan UGM, Laboratorium Biokimia Pusat Antar Universitas
UGM, Laboratorium Penelitian dan Pengujian Terpadu UGM serta Laboratorium Makanan dan Nutrisi Ternak Jurusan Peternakan Fakultas Pertanian UNS.

\section{Bahan dan Alat}

\section{Bahan}

Menir kedelai diperoleh dari UD. Rejeki, Surakarta. Minyak ikan lemuru diperoleh dari UD. Muncar, Banyuwangi. Cairan rumen diambil dari donor induk sapi Peranakan Ongole berfistula, 37\% formaldehid, larutan $\mathrm{Mc}$ Dougall, $\mathrm{HCl}$ pekat, chloroform, methanol, petroleum benzena, dietil eter, heptan, ammonia dan $\mathrm{NaCl}$ jenuh.

\begin{abstract}
Alat
Alat spuit-paralon, Gas Chromatografi (GC) merk Shimadzu (GC14 A/B, WCOT FUSE SILICA 50 meter $0,25 \mathrm{~mm}$ Coating CPCIL-88 dan detector FID suhu kolom $130^{\circ} \mathrm{C}$, suhu injector atau detector $220^{\circ} \mathrm{C}$ ), sentrifuse $4^{0} \mathrm{C}$, timbangan analitik, $\mathrm{pH}$ meter dan wather bath.
\end{abstract}

\section{Parameter}

\section{Kandungan nutrien}

Komposisi kimia dari hasil uji analisis proksimat meliputi kadar air, bahan kering, lemak, protein, serat kasar, air dan kadar abu melalui uji proksimat (AOAC, 2005).

\section{Kadar PUFA}

Komposisi dan kadar berbagai PUFA ditentukan menggunakan metode Sudarmadji et al. (1997) dan AOAC (2005).

\section{Jalan Penelitian}

\section{Proteksi formaldehid}

Menir kedelai dan minyak ikan lemuru dicampur homogen dengan perbandingan 2:1 dan 4:1 dalam bentuk substrat, masing-masing campuran di ditambahkan formaldehid kadar $37 \%$ dengan level $0 \%, 2 \%$ dan $4 \%$ dari bahan 
kering campuran sesuai dengan perlakuan. Substrat campuran menir kedelai dan minyak ikan lemuru yang sudah diproteksi disimpan selama 24 jam dan dianginkan 30 menit sebelum diuji.

\section{Rancangan percobaan}

Rancangan percobaan yang digunakan adalah rancangan acak lengkap pola faktorial $2 \times 3$, sebagai faktor pertama adalah campuran menir kedelai (MK) dan minyak ikan lemuru (L) dengan perbandingan 2:1 dan 4:1, disebut kelompok 2MKL dan 4MKL. Faktor kedua adalah formaldehid $(\mathrm{F})$ dengan level $0 \% \mathrm{~F}, 2 \%$ $\mathrm{F}$ dan $4 \% \mathrm{~F}$. Terdapat 6 kombinasi perlakuan yaitu 2MKL-0\%F (campuran menir kedelai (MK) dan minyak ikan lemuru (L) (2:1) dengan formaldehid (F) level 0\%), 2MKL-2\%F (campuran menir kedelai (MK) dan minyak ikan lemuru (L) (2:1) dengan formaldehid (F) level 2\%), 2MKL-4\%F (campuran menir kedelai (MK) dan minyak ikan lemuru (L) (2:1) dengan formaldehid (F) level 4\%), 4MKL-0\%F (campuran menir kedelai (MK) dan minyak ikan lemuru (L) (4:1) dengan formaldehid (F) level 0\%), 4MKL-2\%F (campuran menir kedelai (MK) dan minyak ikan lemuru (L) (4:1) dengan formaldehid (F) level 2\%) dan 4MKL$4 \% \mathrm{~F}$ (campuran menir kedelai (MK) dan minyak ikan lemuru (L) (4:1) dengan formaldehid (F) level 4\%).
Terhadap masing-masing kombinasi (dengan 3 kali ulangan) dilakukan uji kecernaan in vitro. Pengambilan cairan rumen dari fistula rumen sapi untuk uji in vitro dilakukan pengulangan sebanyak 5 kali dengan selang waktu 7 hari. Untuk parameter fermentasi asam lemak dilakukan pengulangan 3 kali waktu pengambilan cairan rumen.

\section{Analisis hasil}

Data hasil analisis proksimat dihitung rata-rata kemudian dianalisis secara deskritif. Untuk melihat apakah perbedaan yang terjadi signifikan atau tidak, data PUFA dan parameter fermentasi rumen dianalisis menggunakan analisis sidik ragam pola faktorial $2 \times 3$. Untuk parameter yang hasil ujinya signifikan, dilanjutkan dengan uji beda rata-rata menggunakan duncan multiple range test (DMRT).

\section{HASIL DAN PEMBAHASAN}

\section{Profil Substrat Campuran Menir Kedelai- Minyak Ikan Lemuru}

Kandungan nutrien menir kedelai dan minyak ikan lemuru serta substrat campuran menir kedelai-minyak ikan lemuru dengan rasio 2:1 dan 4:1 terproteksi dan tidak terproteksi formaldehid, dapat dilihat pada Tabel 1.

Tabet 1. Kandungan Nutrien (\%) Menir Kedelai dan Minyak Ikan Lemuru Serta Substrat Menir Kedelai-Minyak Ikan Lemuru Terproteksi dan Tidak Terproteksi Formaldehid

\begin{tabular}{|c|c|c|c|c|c|c|c|c|c|}
\hline \multirow[b]{2}{*}{ No } & \multirow[b]{2}{*}{ Nutrisi } & \multirow{2}{*}{$\begin{array}{l}\text { Menir } \\
\text { kedelai }\end{array}$} & \multirow{2}{*}{$\begin{array}{l}\text { Minyak } \\
\text { ikan } \\
\text { lemuru }\end{array}$} & \multicolumn{6}{|c|}{ Perlakuan } \\
\hline & & & & $\begin{array}{l}2 \mathrm{MKL} \\
-0 \% \mathrm{~F}\end{array}$ & $\begin{array}{l}2 \mathrm{MKL} \\
-2 \% \mathrm{~F}\end{array}$ & $\begin{array}{l}2 \mathrm{MKL} \\
-4 \% \mathrm{~F}\end{array}$ & $\begin{array}{l}4 \mathrm{MKL} \\
-0 \% \mathrm{~F}\end{array}$ & $\begin{array}{l}4 \mathrm{MKL} \\
-2 \% \mathrm{~F}\end{array}$ & $\begin{array}{l}4 \mathrm{MKL} \\
-4 \% \mathrm{~F}\end{array}$ \\
\hline 1 & Protein $(\%)$ & 32,94 & 3,70 & 23,05 & 22,58 & 22,32 & 25,06 & 26,94 & 28,19 \\
\hline 2 & Lemak (\%) & 13,44 & 70,40 & 35,77 & 36,97 & 38,26 & 29,81 & 28,99 & 28,88 \\
\hline 3 & $\begin{array}{l}\text { Serat Kasar } \\
(\%)\end{array}$ & 8,47 & 0,75 & 9,47 & 8,52 & 6,96 & 7,88 & 8,25 & 8,04 \\
\hline 4 & $\begin{array}{l}\text { Bahan Kering } \\
(\%)\end{array}$ & 90,54 & 91,19 & 91,94 & 92,50 & 91,35 & 91,11 & 91,07 & 90,77 \\
\hline 5 & $\mathrm{abu}(\%)$ & 7,61 & 8,89 & 6,08 & 5,76 & 6,96 & 6,93 & 7,30 & 7,16 \\
\hline 6 & BETN & 37,54 & 19,56 & 26,63 & 26,17 & 25,50 & 30,32 & 28,52 & 27,73 \\
\hline
\end{tabular}


Substrat menir kedelai:minyak ikan lemuru (4:1) mengandung kadar protein 25,06$28,19 \%$ yang lebih tinggi $22,32-23,05 \%$ dan kadar lemak 28,88-29,81\% yang lebih rendah $35,77-38,26 \%$ dari pada substrat menir kedelai:minyak ikan lemuru (2:1). Hal ini menunjukkan bahwa substrat dengan porsi menir kedelai yang lebih banyak mampu menyediakan protein yang lebih tinggi dan lemak yang lebih rendah. Menir kedelai mengandung protein di atas $35 \%$ juga kaya asam lemak linoleat sedangkan minyak ikan lemuru kaya asam lemak linolenat (Riyanto, 2010). Menir kedelai merupakan kulit biji kedelai yang diperoleh dari proses pengelupasan biji kedelai dari polongnya kemudian kulit dikeringkan diperoleh menir kedelai berbentuk pecahan kedelai. Menir kedelai merupakan sumber utama asam liloneat atau asam lemak omega-6 dan asam arachidonat. Minyak ikan lemuru (Sardinella longiceps) merupakan limbah hasil pengolahan ikan lemuru dari pembuatan tepung ikan yang banyak mengandung asam lemak tak jenuh, utamanya asam linolenat (Riyanto et al., 2011).

\section{Kadar Asam Lemak Substrat Menir Kedelai-Minyak Ikan Lemuru}

Kadar asam lemak substrat menir kedelai-minyak ikan lemuru dengan rasio 2:1 dan 4:1 terproteksi dan tidak terproteksi formaldehid, dapat dilihat pada Tabel 2.

Tabel 2. Kadar Asam Lemak (Mg/100g) Substrat Menir Kedelai-Minyak Ikan Lemuru Terproteksi dan Tidak Terproteksi

\begin{tabular}{|c|c|c|c|c|c|c|}
\hline \multirow[b]{2}{*}{ Asam lemak } & \multicolumn{6}{|c|}{ Perlakuan } \\
\hline & $\begin{array}{l}2 \mathrm{MKL} \\
-0 \% \mathrm{~F}\end{array}$ & $\begin{array}{c}2 \mathrm{MKL}- \\
2 \% \mathrm{~F}\end{array}$ & $\begin{array}{c}2 \mathrm{MKL}- \\
4 \% \mathrm{~F}\end{array}$ & $\begin{array}{l}4 \mathrm{MKL} \\
-0 \% \mathrm{~F}\end{array}$ & $\begin{array}{c}\text { 4MKL- } \\
2 \% \mathrm{~F}\end{array}$ & $\begin{array}{l}4 \mathrm{MK}- \\
4 \% \mathrm{~F}\end{array}$ \\
\hline \multicolumn{7}{|l|}{ SFA : } \\
\hline Laurat C12:0 & 2,42 & 1,75 & 2,08 & 0,60 & 2,83 & 2,46 \\
\hline Miristat C14:0 & 248,33 & 189,95 & 251,35 & 106,89 & 141,12 & 143,14 \\
\hline Pentadecanoat C15:0 & 13,86 & 10,65 & 15,38 & 6,01 & 141,12 & 8,31 \\
\hline Palmitat C16:0 & 179,62 & 253,70 & 225,65 & 172,91 & 249,82 & 220,30 \\
\hline Heptadecanoat C17:0 & 13,69 & 10,11 & 15,59 & 5,94 & 8,63 & 8,33 \\
\hline Stearat C18:0 & 66,24 & 238,95 & 69,81 & 186,81 & 0,11 & 238,21 \\
\hline Behenat C22:0 & 100,22 & 85,26 & 112,60 & 44,97 & 53,08 & 64,68 \\
\hline Lignocerat C24:0 & 3,65 & 3,34 & 5,74 & 2,49 & 3,78 & 2,94 \\
\hline \multicolumn{7}{|l|}{ UFA : } \\
\hline \multicolumn{7}{|l|}{ MUFA: } \\
\hline Palmitoleat C16:1 & 179,62 & 133,48 & 181,37 & 79,13 & 135,38 & 104,54 \\
\hline Oleat C18:1 & 148,64 & 244,74 & 152,65 & 173,37 & 196,74 & 265,23 \\
\hline Eurat C22:1 & 168,42 & 145,56 & 176,41 & 72,29 & 101,32 & 103,42 \\
\hline Nervonat C24:1 & $<0,00$ & 0,28 & 0,50 & $<0,00$ & 0,30 & $<0,00$ \\
\hline \multicolumn{7}{|l|}{ PUFA : } \\
\hline Linoleat C18:2 & 142,62 & 112,38 & 159,21 & 95,54 & 103,15 & 118,68 \\
\hline Linolenat C18:3 & 1,35 & 1,01 & 12,74 & 0,68 & 8,60 & 0,83 \\
\hline Gama Linolenat C20:3 & 11,76 & 8,20 & 36,07 & 5,87 & 21,55 & 8,33 \\
\hline Arachidonat C20:4 & 6,87 & 204,64 & 247,52 & 3,11 & 139,82 & 143,55 \\
\hline SFA & 628,04 & 698,21 & 526,62 & 600,49 & 688,37 & 793,71 \\
\hline UFA & 659,29 & 966,47 & 430,00 & 706,85 & 744,58 & 850,29 \\
\hline
\end{tabular}




\begin{tabular}{lrrrrrr} 
MUFA & 496,68 & 510,93 & 324,79 & 433,73 & 473,19 & 524,07 \\
PUFA & 162,61 & 455,54 & 105,21 & 273,12 & 271,39 & 326,22 \\
MUFA:PUFA & 3,05 & 1,12 & 3,09 & 1,59 & 1,74 & 1,61 \\
\hline
\end{tabular}

Keterangan: SFA: saturated fatty acids, UFA: unsaturated fatty acid, MUFA: mono unsaturated fatty acids, PUFA: poly unsaturated fatty acids.

Hasil penelitian menunjukkan bahwa asam lemak jenuh ganda atau PUFA terutama asam lemak linoleat dan asam arachidonat pada substrat yang diproteksi memiliki kadar yang lebih tinggi dari pada yang tidak diproteksi baik pada substrat menir kedelai:minyak ikan lemuru (2:1) maupun menir kedelai:minyak ikan lemuru (4:1). Senyawa kimia formaldehida disebut juga dengan metanal atau formalin merupakan aldehida dengan rumus kimia $\mathrm{H}_{2} \mathrm{CO}$ berbentuk gas atau cair dikenal sebagai formalin. Formaldehid bisa larut dalam air dan biasanya dijual dalam kadar larutan 37\% dengan kadar antara 10-40\%. Formaldehid secara khusus dapat digunakan sebagai bahan proteksi nutrisi suatu bahan pakan seperti protein dan asam lemak agar tidak didegradasi dan hidrogenasi oleh mikrobia rumen. Metode proteksi lemak menggunakan matrik protein yang diproteksi formaldehid didasarkan atas penurunan kecernaan protein akibat dari perubahan struktur tiga dimensi oleh aldehid atau formaldehid. Metode ini disebut juga dengan kapsulasi yang dapat memproteksi lemak dari metabolisme di rumen hingga $90 \%$ (Emanuele dan Putnam, 2006). Riyanto et al. (2011) melaporkan bahwa bahan pakan sumber PUFA berasal dari tepung ikan, minyak ikan lemuru, tepung menir kedelai dan minyak sawit mempunyai kinetik fermentasi rumen yang setara atau sebanding. Suplementasi tepung menir kedelai diproteksi 37\% formaldehid dan minyak ikan lemuru disaponikasi garam-Ca menunjukkan hasil konsentrasi $\mathrm{NH}_{3}$ yang paling optimal dibandingkan ransum disuplementasi dengan tepung ikan dan minyak sawit.

\section{Kadar Asam Lemak Hasil Fermentasi Cairan Rumen Menir Kedelai dan Minyak Ikan Lemuru Secara In Vitro}

Pengaruh perbedaan substrat menir kedelai-minyak ikan lemuru dan level formaldehid terhadap kadar asam lemak cairan rumen hasil fermentasi, lihat Tabel 3. 
Tabel 3. Kadar Asam Lemak (Mg/100g) Cairan Rumen Hasil Fermentasi Substrat Menir KedelaiMinyak Ikan Lemuru yang Diproteksi Formaldehid Secara In Vitro

\begin{tabular}{|c|c|c|c|c|c|}
\hline \multirow{2}{*}{$\begin{array}{c}\text { Asam } \\
\text { Lemak }\end{array}$} & \multirow[b]{2}{*}{ Substrat } & \multicolumn{3}{|c|}{ Formaldehid } & \multirow{2}{*}{$\begin{array}{l}\text { Rata- } \\
\text { rata }\end{array}$} \\
\hline & & $0 \% \mathrm{~F}$ & $2 \% \mathrm{~F}$ & $4 \% \mathrm{~F}$ & \\
\hline Laurat & $2 \mathrm{MKL}$ & $1,93 \pm 1,45$ & $1,52 \pm 2,60$ & $0,74 \pm 0,96$ & $1,40 \pm 0,60$ \\
\hline C12:0 & $4 \mathrm{MKL}$ & $3,24 \pm 2,71$ & $2,61 \pm 3,08$ & $4,00 \pm 1,27$ & $3,28 \pm 0,70$ \\
\hline Rata-rata & & $2,59 \pm 0,93$ & $2,06 \pm 0,77$ & $2, .37 \pm 2,3$ & $2,34 \pm 1,33$ \\
\hline Miristat & $2 \mathrm{MKL}$ & $31,96 \pm 10,58$ & $26,87 \pm 3,54$ & $25,55 \pm 23,10$ & $28,13 \pm 3,38$ \\
\hline C14:0 & 4MKL & $24,21 \pm 19,98$ & $44,63 \pm 12,64$ & $45,39 \pm 0,95$ & $38,08 \pm 12,01$ \\
\hline Rata-rata & & $28,09 \pm 5,48$ & $35,75 \pm 12,56$ & $35,47 \pm 14,03$ & $33,10 \pm 4,35$ \\
\hline Pentadecanoa & 2MKL & 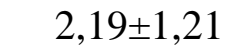 & $1,92 \pm 0,96$ & $1,97 \pm 1,76$ & $2,03 \pm 0,15$ \\
\hline t C15:0 & 4MKL & $2,25 \pm 1,67$ & $1,22 \pm 1,51$ & $0,27 \pm 0,28$ & $1,25 \pm 0,99$ \\
\hline Rata-rata & & $2,22 \pm 0,04$ & $1,57 \pm 0,49$ & $1,12 \pm 1,20$ & $1,64 \pm 0,55$ \\
\hline Palmitoleat & 2MKL & $25,12 \pm 12,19$ & $24,72 \pm 2,05$ & $21,30 \pm 20,60$ & $23,72 \pm 2,10$ \\
\hline $\mathrm{C} 16: 1$ & $4 \mathrm{MKL}$ & $21,13 \pm 15,81$ & $32,55 \pm 9,01$ & $61,75 \pm 14,39$ & $38,48 \pm 20,95$ \\
\hline Rata-rata & & $23,12 \pm 2,82^{\mathrm{a}}$ & $28,64 \pm 5,53^{\mathrm{ab}}$ & $41,53 \pm 28,6^{b}$ & $31,10 \pm 9,44$ \\
\hline Palmitat & $2 \mathrm{MKL}$ & $74,16 \pm 12,22$ & $62,16 \pm 32,86$ & $124,54 \pm 55,32$ & $86,95 \pm 33,10$ \\
\hline C16:0 & $4 \mathrm{MKL}$ & $67,24 \pm 21,32$ & $152,22 \pm 47,08$ & $192,12 \pm 25,65$ & $137,19 \pm 63,78$ \\
\hline Rata-rata & & $70,70 \pm 4,89^{\mathrm{a}}$ & $107,19 \pm 63.68^{\mathrm{a}}$ & $158,33 \pm 47,78^{\mathrm{b}}$ & $112,07 \pm 44,02$ \\
\hline Heptadecanoa & $2 \mathrm{MKL}$ & $2,48 \pm 0,96$ & $1,70 \pm 0,77$ & $1,86 \pm 1,43$ & $2,01 \pm 0,41$ \\
\hline t C17:0 & $4 \mathrm{MKL}$ & $1,42 \pm 0,16$ & $1,34 \pm 1,62$ & $3,10 \pm 2,02$ & $1,95 \pm 0,99$ \\
\hline Rata-rata & & $1,07 \pm 5,95$ & $1,52 \pm 0,25$ & $2,48 \pm 0,87$ & $1,98 \pm 0,48$ \\
\hline Oleat & $2 \mathrm{MKL}$ & $28,14 \pm 10,29$ & $32,74 \pm 4,99$ & $44,55 \pm 13,16$ & $35,14 \pm 8,46$ \\
\hline C18:1 & 4MKL & $20,28 \pm 7,51$ & $48,32 \pm 7,82$ & $53,20 \pm 15,49$ & $40,60 \pm 17,77$ \\
\hline Rata-rata & & $24,21 \pm 5,56^{\mathrm{a}}$ & $40,53 \pm 11,02^{b}$ & $48.87 \pm 6,12^{b}$ & $37,87 \pm 12,54$ \\
\hline Stearat & $2 \mathrm{MKL}$ & $3,55 \pm 1,46$ & $2,90 \pm 0,95$ & $9,15 \pm 1,06$ & $5,20 \pm 3,44$ \\
\hline C18:0 & 4MKL & $4,18 \pm 3,22$ & $11,55 \pm 6,40$ & $15,83 \pm 5,17$ & $10,52 \pm 5,89$ \\
\hline Rata-rata & & $3,86 \pm 0,44^{\mathrm{a}}$ & $7,22 \pm 6,12^{\mathrm{a}}$ & $12,49 \pm 4,72^{\mathrm{b}}$ & $7,86 \pm 4,35$ \\
\hline Linoleat & $2 \mathrm{MKL}$ & $29,66 \pm 2,46$ & $27,83 \pm 7,18$ & $42,74 \pm 3,21$ & $33,41 \pm 8,13$ \\
\hline C18:2 & 4MKL & $19,48 \pm 3,21$ & $59,79 \pm 1,93$ & $151,53 \pm 76,24$ & $76,93 \pm 67,67$ \\
\hline Rata-rata & & $24,57 \pm 7,20^{\mathrm{a}}$ & $43,81 \pm 22,60^{\mathrm{a}}$ & $97,13^{b} \pm 76,93^{b}$ & $55,17 \pm 37,59$ \\
\hline Arachidonat & $2 \mathrm{MKL}$ & $15,84 \pm 3,75$ & $25,64 \pm 8,00$ & $24,17 \pm 8,42$ & $21,89 \pm 5,29$ \\
\hline C20:4 & $4 \mathrm{MKL}$ & $13,13 \pm 4,19$ & $44,97 \pm 15,13$ & $41,52 \pm 2,47$ & $33,21 \pm 17,47$ \\
\hline Rata-rata & & $14,49 \pm 1,91^{\mathrm{a}}$ & $35,31 \pm 13,67^{\mathrm{b}}$ & $32,85 \pm 12,26^{\mathrm{b}}$ & $27,55 \pm 11,38$ \\
\hline Gama & 2MKL & $6,42 \pm 2,89$ & $5,61 \pm 0,06$ & $11,71 \pm 4,45$ & $7,91 \pm 3, .31$ \\
\hline Linolenat & & & & & \\
\hline C20:3 & 4MKL & $3,84 \pm 0,10$ & $9,03 \pm 0,65$ & $12,59 \pm 3,00$ & $8,49 \pm 4,40$ \\
\hline Rata-rata & & $5,13 \pm 1,82^{\mathrm{a}}$ & $7,32 \pm 2,41^{\mathrm{a}}$ & $12,15 \pm 0,62^{b}$ & $8,20 \pm 3,59$ \\
\hline Linolenat & $2 \mathrm{MKL}$ & $1.82 \pm 1,81$ & $1,40 \pm 0,35$ & $3,98 \pm 1,12$ & $2,40 \pm 1,39$ \\
\hline C18:3 & 4MKL & $1,63 \pm 0,45$ & $5,86 \pm 2,02$ & $5,97 \pm 1,86$ & $4,49 \pm 2,47$ \\
\hline Rata-rata & & $1,3 \pm 0,14^{\mathrm{a}}$ & $3,63 \pm 3,16^{\mathrm{b}}$ & $4,98 \pm 1,40^{\mathrm{b}}$ & $3,44 \pm 1,63$ \\
\hline Behenat & $2 \mathrm{MKL}$ & $26,40 \pm 14,65$ & $18,01 \pm 5,71$ & $18,19 \pm 6,33$ & $20,87 \pm 4,79$ \\
\hline $\mathrm{C} 22: 0$ & 4MKL & $23,69 \pm 17,17$ & $30,27 \pm 18,62$ & $39,88 \pm 10,27$ & $31,28 \pm 8,14$ \\
\hline Rata-rata & & $25,04 \pm 1,92$ & $24,14 \pm 8,67$ & $29,03 \pm 15,33$ & $26,07 \pm 2,60$ \\
\hline Eurat & $2 \mathrm{MKL}$ & $7,16 \pm 1,88$ & $5,14 \pm 4,45$ & $8,20 \pm 0,87$ & $6,83 \pm 1,56$ \\
\hline C22:1 & 4MKL & $4,39 \pm 0,60$ & $12,96 \pm 1,19$ & $16,86 \pm 5,94$ & $11,40 \pm 6,38$ \\
\hline
\end{tabular}




\begin{tabular}{|c|c|c|c|c|c|}
\hline Rata-rata & & $5,78 \pm 1,96$ & $9,05 \pm 5,53$ & $12,53 \pm 6,13$ & $9,12 \pm 3,38$ \\
\hline Lignocerat & $2 \mathrm{MKL}$ & $1,41 \pm 0,74$ & $0,48 \pm 0,45$ & $0,39 \pm 0,67$ & $0,76 \pm 0,57$ \\
\hline $\mathrm{C} 24: 0$ & $4 \mathrm{MKL}$ & $1,27 \pm 0,98$ & $0,67 \pm 1,16$ & $0,88 \pm 1,29$ & $0,94 \pm 0,30$ \\
\hline Rata-rata & & $1,34 \pm 0,10$ & $0,58 \pm 0,13$ & $0,63 \pm 0,35$ & $0,85 \pm 0,43$ \\
\hline Nervonat & $2 \mathrm{MKL}$ & $1,09 \pm 0,83$ & $0,91 \pm 0,33$ & $0,54 \pm 0,91$ & $0,85 \pm 0,28$ \\
\hline C24:1 & 4MKL & $0,49 \pm 0,40$ & $1,18 \pm 1,03$ & $2,09 \pm 1,87$ & $1,25 \pm 0,80$ \\
\hline Rata-rata & & $0,79 \pm 0,42$ & $1,05 \pm 0,19$ & $1,31 \pm 1,09$ & $1,05 \pm 0,26$ \\
\hline
\end{tabular}

Keterangan: Superskrip yang berbeda pada baris yang sama menunjukkan perbedaan nyata $(\mathrm{P}<0,05)$. 2MKL: campuran menir kedelai:minyak ikan lemuru (2:1), 4MKL: campuran menir kedelai:minyak ikan lemuru (4:1).

Perbedaan rasio menir kedelai:minyak ikan lemuru dan interaksinya dengan perbedaan level formaldehid tidak berpengaruh $(\mathrm{P}>0,05)$ terhadap kadar asam lemak cairan rumen fermentasi in vitro. Perbedaan level formaldehid menghasilkan asam lemak palmitoleat, palmitat, oleat, stearat, linoleat, arachidonat, gama linolenat dan linolenat yang berbeda nyata $(\mathrm{P}<0,05)$, namun berbeda tidak nyata $(\mathrm{P}>0,05)$ terhadap kadar asam lemak laurat, miristat, pentadecanoat, heptadecanoat, behenat, eurat, lignocerat dan nervonat.

Dari hasil DMRT tampak bahwa penggunaan formaldehid pada level $2 \%$ dan $4 \%$ untuk proteksi substrat campuran menir kedelai dengan minyak ikan lemuru menghasilkan kadar asam lemak oleat, arachidonat dan linolenat yang berbeda tidak nyata $(\mathrm{P}>0,05)$, namun kedua perlakuan tersebut menghasilkan kadar yang lebih tinggi dari pada tanpa proteksi formaldehid $(\mathrm{P}<0,05)$. Penggunaan formaldehid dengan level 4\% menunjukkan hasil kadar asam lemak palmitat, stearat, gama linolenat dan linolenat yang lebih tinggi $(\mathrm{P}<0,05)$ dari pada proteksi menggunakan formaldehid level $2 \%$ dan tanpa proteksi, sedangkan penggunaan proteksi formaldehid level $4 \%$ menunjukkan hasil asam lemak palmitoleat yang berbeda tidak nyata $(\mathrm{P}>0,05)$ dengan level $2 \%$ namun penggunaan formaldehid level $4 \%$ nyata lebih tinggi kadarnya dibanding dengan tanpa proteksi formaldehid $(\mathrm{P}<0.05)$.
Hasil ini menunjukkan bahwa proteksi $2 \%$ atau $4 \%$ mampu menyediakan asam lemak tak jenuh ganda atau PUFA terutama asam lemak oleat, arachidonat dan linoleat dalam kadar yang lebih tinggi dari pada tanpa proteksi formaldehid pada campuran substrat menir kedelai: minyak ikan lemuru, sehingga berpotensi sebagai penyedia prekursor hormon PGF2 $\alpha$ untuk lisis corpus luteum. Pada level konsentrasi formaldehid tinggi akan semakin kuat ikatan proteksinya karena terjadi peningkatan ikatan silang antara protein dan aldehid. Hasil penelitian ini membuktikan bahwa proteksi menggunakan formaldehid telah terjadi ikatan silang atau jembatan methilen dari nitrogen dalam protein menir kedelai dengan gugus aldehid formaldehid, dengan demikian asam lemak jenuh dan protein akan terproteksi dari degradasi dan biohedrogenasi rumen dan lolos atau fat-protein rumen by pass langsung menuju saluran pencernaan post rumen. Menurut Akif et al. (2006) perlakuan peningkatan level formaldehid $0,3 \%$ dan $0,6 \%$ memberikan hasil peningkatan penyerapan total asam amino esensial dan biovalaitabiltas protein soybean meal. Penggunaan matrik protein yang diproteksi formaldehid berdasarkan penurunan kecernaan protein akibat dari perubahan struktur tiga dimensi oleh aldehid atau formaldehid (Emanuele dan Putnam, 2006). Induk sapi post partum yang menerima pakan soybean whole roast, linseed, palm oil sampai hari ke-40 diperoleh 
hasil penelitian bahwa pemberian soybean whole roast menyebabkan involusi uterus dan estrus pertama lebih awal terjadi dan cepat daripada yang diberi pakan linseed dan palm oil (Dirandeh et al., 2013). Hal ini menunjukkan bahwa ada indikasi proteksi formaldehid mampu mempertahankan proses biohidrogenasi selama dalam rumen. Proteksi formaldehid pada lemak menggunakan ikatan aldehid dengan matrik dapat berhasil meloloskan asam lemak dari metabolism rumen hingga $90 \%$ melalui perubahan struktur tiga dimensi aldehid (Emanuele dan Putnam, 2006).

\section{KESIMPULAN}

Dari penelitian disimpulkan bahwa (1) campuran menir kedelai:minyak ikan lemuru dengan rasio 4:1 mempunyai nilai nutrien lebih baik dibanding rasio 2:1 dan (2) formaldehid level $2 \%$ menunjukkan hasil lebih baik apabila digunakan sebagai bahan proteksi substrat campuran menir kedelai:minyak ikan lemuru rasio 4:1 dibanding rasio 2:1.

\section{DAFTAR PUSTAKA}

Akif, M.Y.R.K1, T. Aksu, M. Gul and D. Bolat. 2006. The effect of soybean meal treated with formaldehyde on amount of protected protein in the rumen and absorption of amino acid from small intestines. Turk. J. Vet. Anim. Sci. 30: 457-463.

AOAC, 2005. Official Methods of Analsis AOAC INTERNATIONAL The Association of Official Analytical Chemist. 18th Edition, 2005, ISBN 0935584-77-3. Published by AOAC International Suite $500 \quad 481 \quad$ Nrth Frederick Avenue, Gaithersburg,Mary Land 20877, USA.

Dirandeh, E., A. Towhidi., S. Zeinoaldini., M. Ganjkhanlou., Z.A. Pirsaraei Effects of different polyunsaturated fatty acid supplementations during the post partum periods of early lactating dairy cows on milk yield, metabolic responses and reproductive performances. J. Anim. Sci. 91: 713721 (Abstr.).

Emanuele, S.M. and D. Putnam. 2006. Encapsulating Nutrients to improve reproduction and nitrogen utilization in ruminants. In proceedings: Ruminant Nutrition Symposium, February 1-2, 2006, Florida Best Western Gateway Grand, Gainesville FL.

Lourenc, M., E. Ramos-Morales and R.J. Wallace. 2010. The role of microbes in rumen lipolysis and biohydrogenation and their manipulation. Animal (2010), 4(7): 1008-1023 \& The Animal Consortium 2010.

Mohammadian-Tabrizi, H.R., H. Sadeghipanah, M. Chamani, Y. Ebrahim-Nejad1 and H. Fazaeli. 2011. In vitro gas production of wheat grain flour coated with different fat types and levels. African J. Biotech. 10(39): 7710-7716.

Riyanto, J., S.D. Widyawati dan W. Pratitis. 2011. Suplementasi PUFA (Poly Unsaturated Fatty Acid) dalam konsentrat dari bahan pakan lokal pada usaha feedlot sapi silangan berbasis pakan basal jerami padi fermentasi untuk dihasilkan daging sapi rendah lemak dan kolesterol serta tinggi asam lemak tak jenuh. Laporan penelitian "Hibah Startegi Nasional" Dibiayai Oleh Direktorat Jenderal Pendidikan Tinggi, Kementrian Pendidikan Nasional.

Riyanto, J. 2010. Kinetic And Degradability Of Feedlot System Beef Cattle Fattening Ration Supplemented With Protected Pufa (Poly Unsaturated Fatty Acids) Fodder Source Material. Proceedings International Seminar on Prospects and Challenges of Animal Production in Developing Countries in 
the 21st Century ( $1^{\text {st }}$ APIS-2010) Faculty of Animal Husbandry University of Brawijaya MalangIndonesia, March 23-25, 2010 ISBN : 978-602-8074-69-1.

Sudarmadji, S., Haryono, B dan Suhardi. 1977. Prosedur analisa untuk bahan makanan dan pertanian. Liberty. Yogyakarta.

Wallace, R.J and M.A. Cotta. 1988. Metabolism in nitrogen-containing compounds. In: The rumen microbial ecosistem. Edited by P.N. Hobson. Elsevier Applied Science. London. UK. 